\title{
Effect of Tax Evasion on Economic Development of Yobe State, Nigeria
}

\author{
Abdulhamid Ellawule*
}

Department of Accounting, Federal University, Gashua, Nigeria

\begin{abstract}
This paper intends to evaluate the effect of tax evasion on the economic development of Yobe state, Nigeria. The importance of tax cannot be overemphasized. Taxes were used to administer the North in pre-colonial era before oil production in 1958. The current loss of fund by the Nigerian government resulting from fall in oil revenue leads to this question, why is Yobe not generating enough funds through tax to develop the state? This study also intends to find out why is tax revenue that are so far collected are not used to develop the economy of the state the way it is done in other states like Lagos and Kano? The data for the study is secondary and the research approach is quantitative and Chi-square is employed for data analysis using Statistical Package for Social Sciences (SPSS) version 20. Based on the objective of the study, it is found out the tax evasion has significant effect of the economic development of the state. It is recommended among others that the state government should improve on the governance and to reduce insurgency in the state.
\end{abstract}

Keywords: Tax evasion; Tax administration; Economic development; VAIDS

\section{Introduction}

Government needs money in other to provide social obligations. These social obligations amongst other are provision of infrastructural facilities and social services [1]. Nightingale [2] and Lymer and Oats [3], state that taxation is meant to address the following challenges:

- To raise revenue to finance government expenditure;

- For redistribution of wealth and income to promote welfare of the citizenry; and

- To regulate economy for conducive business activities.

Murkur [4], however, states that meeting these obligations is huge and therefore, citizens are enjoined to perform their civic duties by paying their taxes. In pre-colonial Northern Nigeria administration headed by the Emirs, there was an organized system of tax collection and distribution. The British took advantage of the centralized system of administering tax in Northern Nigeria to introduce tax in that region of the country as an alternative to raise funds to administer the region via the indirect system of government [1]. There were different types of taxes imposed on livestock and agricultural products; zakka, gada, kindin, etc. to raise funds. Fagbemi et al. [1] state that this tax was introduced in the Western and Eastern parts of the country in 1917 and 1928 respectively through the Native Revenue Ordinances. Naiyelu [5] states that success of any tax system depends on how it is managed the extent of the interpretation and implementation. ICAN [6] states that there is no generally accepted definition of taxation in any Nigerian tax laws but can however be defined as:

"A compulsory contribution levied by a sovereign power, on the incomes, profits, goods, services or properties of individuals and corporate persons, trusts and settlements. Such taxes when collected are used for carrying out governmental functions, such as maintenance of law and order, provision of infrastructure, health and education of the citizens, or as a fiscal tool for controlling the economy".

The lack of payment of tax by the informal sector, the connivance of the tax authorities and the union in the formal sector serve as a clog in the wheel of the successful implementation of tax policies in Nigeria [7]. Odusola [7] equally states the lop-sidedness of Nigerian tax systems which is characterized by inequitable tax laws and dominated by oil revenue. The importance of taxation as stated by Nightingale [2], and Lymer and Oats [3] has the Yobe state government used this avenue to develop her state?

This will afford the opportunity to examine critically how Yobe state has fared aside from the money from oil revenue. From research conducted by different researchers, there are different findings which range from the lack of tax authority's inability to manage tax matters in Nigeria to lack of implementation of tax laws and total waste of the funds generated.

The study will strive to unravel why despite the numerous tax strategies at the disposal of the state government; she cannot generate enough funds for her development and in addition determine the effect of tax evasion on the state economic development.

\section{Review of Related Literature}

\section{Conceptual review}

Tax evasion: Tax evasion is a situation whereby a taxpayer out rightly refuses to pay tax, or tries illegally to minimize his tax liability. Tax evasion is fraud and deceit, by deliberately refusing to declare all sources of income when filing returns or understate income in tax returns [6]. Incomes are supposed to be declared even if they are tax exempt. Gurama et al. [8] state that tax evasion is either full or partial; it's full when a citizen who qualifies to pay tax refuses to get registered for the purpose of paying tax while it's said to be partial when a tax payer manipulates his income in other to reduce his tax burden. Tax evasion and tax avoidance as opine by Adebisi and Gbegi [9] are one of the main problems of tax system in Nigeria and Africa and are described as 'twin devils' which cause the difference between actual

*Corresponding author: Abdulhamid Ellawule, Lecturer, Department of Accounting, Federal University, Gashua, Nigeria, Tel: +2348069252961; E-mail: ellawule@yahoo.com

Received January 18, 2018; Accepted January 29, 2018; Published February 08, 2018

Citation: Ellawule A (2018) Effect of Tax Evasion on Economic Development of Yobe State, Nigeria. J Account Mark 7: 262. doi: 10.4172/2168-9601.1000262

Copyright: (c) 2018 Ellawule A. This is an open-access article distributed under the terms of the Creative Commons Attribution License, which permits unrestricted use, distribution, and reproduction in any medium, provided the original author and source are credited. 
and potential revenue. ICAN [6] states that tax avoidance is a situation whereby a taxpayer arranges his financial affairs in such a way that he pays least possible amount of tax without breaking any tax law. ICAN [10] opines that tax evasion can be achieved through:

- Understating income

- Overstating expenditure

- Making false claims for allowances and relief; and

- Omission from tax returns of chargeable income.

"No one really likes paying taxes yet they are inevitable for the provision of social welfare" [2]. Impact of tax cannot be over emphasized yet some believe by paying tax is enriching selected few at the expense of all.

Good tax systems should be efficient, neutral, flexible and simple. "An efficient tax may not necessary be considered fair and the one that is considered equitable may not be efficient" [11]. Tax is a burden to some but to others it is a civic responsibility to pay tax, so people abhor tax payment and as such a few are enthusiastic when it comes to paying tax [12]. In other to avoid these sharp practices by some companies, the Company Income Tax Act contains general provisions on antiavoidance rules. Companies are enjoined to comply with arm's length principle when dealing with related parties [13]. To encourage tax defaulters to pay their taxes that made the Federal Republic of Nigeria to introduce Voluntary Assets and Income Declaration Scheme (VAIDS).

VAIDS: VAIDS is an acronym for Voluntary Assets and Incomes Declaration Scheme. It is a scheme of the federal Republic of Nigeria which gives once-in-a-life-time opportunity to tax payers to fully and honestly declare all their assets and incomes from all sources which had previously not been exposed to the tax authorities and to pay tax on the assets and the incomes [14]. The then Acting President, Yemi Osinbajo, signed an Executive Order to back the Voluntary Asset and Income Declaration Scheme [15]. This executive order is an amnesty which covers the period of nine months, from $1^{\text {st }}$ July, 2017 to March 31,2018 . Since it is a voluntary disclosure programme, the noncompliant taxpayers can regularize their tax position without being penalized or prosecuted during the amnesty window. The Minister of Finance, Kemi Adeosun says, "Many Nigerians have lost assets in the course of trying to conceal them from the authorities. Such losses typically occur in the event of death or an urgent need to liquidate assets when required documentation and proof of ownership cannot be provided. The global focus on illicit financial flows is such that global regulations will only become tighter with time, thus this opportunity to regularize ownership of assets should be seized as proper declaration allows assets to be legally and formally held by the true owner". The implementation of VAIDS is done by tax administration of different tiers of government [16].

Tax administration: Tax system has three components: the tax policy, the tax laws and the administration of these tax laws. Tax policy helps direct government intentions and actions towards achieving set goals. Government could decide to concentrate on consumption tax which could help reduce tax evasion or government could use tax reduction for individuals to stimulate the economy as a result of high disposable income [17]. Nigeria has different tax laws which are reviewed periodically. These tax laws are:

a. Personal Income Tax (Amendment) Act 2011;

b. Companies Income Tax Act Cap C21 LFN 2004 (as amended); c. Petroleum profits Tax Act Cap P13 LFN 2004 (as amended);

d. Capital Gains Tax Act Cap C1 2004;

e. Value Added Tax Act Cap V1 LFN 2004 (as amended);

f. Education Tax Act Cap E4 LFN 2004; and

g. Stamp Duties Act Cap S8 LFN 2004.

Different tiers of government in Nigeria administer tax. Different machineries are set up by the federal government because of the exclusive legislative authority to ensure compliance and defaulters are penalized. Tax administration- to ensure implementation of these tax laws, different bodies are charged with the administration of tax in Nigeria. These bodies are:

a. The Federal Inland Revenue Service;

b. The State Boards of Internal Revenue; and

c. The Local Government Revenue Committee.

Taxes and levies to be collected by State Governments are;

1. Pay As You Earn (PAYE);

2. Withholding tax on individuals;

3. Capital gains tax on individuals;

4. Stamp duties on investments executed by individuals;

5. Pools betting, lotteries, gaming and casino taxes;

6. Road taxes; and

7. Business premises registration fees, for:

(a) Urban areas as defined by each State:

- N10,000.00 (maximum) for registration

- N5,000.00 for annual renewal of registration.

(b) Rural areas as defined by each State:

- $\mathrm{N} 2,000.00$ for registration; and

- N1,000 for annual renewal of registration.

8. Development Levy (individuals only), not more than N100.00 per annum on all taxable individuals;

9. Naming of street registration fees in State Capital;

10. Right of Occupancy Fees on Lands owned by the State in urban cities of the state; and

11. Market taxes and levies where state finance is involved [6].

Income generated by the state helps improve the economic development of that state.

Economic development: Measuring a country's economic development has gone beyond the country's Gross Domestic Product (GDP) or Gross National Product (GNP), which only measures economic growth. The measurement of the level of human development through the use of Gross National Product (GNP) for different countries was first criticized by the pioneer United Nation Report of 1954 in which recommendations against the standard of living was made. Human Development Index was developed in 1990 as part of United Nation Development Programme (UNDP) [18]. The measurement of standard of living has been represented by some 
indicators which serve as HDI. The intention of using this index rather than economic growth was for ease of comparison, transparent device for measuring human development progress and to attract the attention of policy makers [19]. There are three major dimensions of human development components: knowledge, longevity and access to resources. These three important choices are "...for people lead a long and healthy life, to acquire knowledge and to have access to resources needed for a decent standard of living" [20,21].

The attainment of HD can be measured through the following indicators:

- Life expectancy at birth;

- Mean year of schooling;

- Expected year of schooling; and

- Gross National Income per capita.

HDI is a geometric mean of indices used in the dimension [22]. An HD Index has four classes; low development, medium development, high and very high development. An index of 0-0.49 means low development; an index of 0.5-0.69 means medium development, an index of 0.7 to 0.79 means high development, above 0.8 means very high development [18].

\section{Empirical review}

From their study, ethics of tax evasion, Fagbemi et al. [1] used a survey for their study. The researchers focused on business tax payers and left out likely tax evaders like the contractors and professionals like the lawyers, doctors and accounting firms. The analysis of the study used both descriptive and inferential statistics. They found out that the level of tax evasion is significantly higher when government is corrupt than any other views. In their study, effect of tax avoidance and tax evasion on personal income tax in Nigeria, Adesi and Gbegi [9] administered questionnaires on employees of Federal Inland Revenue Service in Abuja. Just like Fagbemi et al. [1], some of the elements in personal income tax like contractors and professionals are left out of the study. ANOVA was used to analyse two hypotheses; the relationship tax avoidance, tax evasion and personal income tax administration in Nigeria, and the relationship between tax rates, tax avoidance and tax evasion. The researchers' use of ANOVA to test relationship brings to question whether the study is measuring 'effect' or 'relationship'. The study found out that good governance will discourage tax avoidance and tax evasion. It equally found out that tax avoidance and tax evasion is as a result of high tax rate. Okafor [23] in his study used regression to analyse a hypothesis on federal tax collected and GDP in Nigeria. The study found out that there is a strong significant relationship between GDP and federally tax revenue generation. The researcher failed to discuss what economic development is. Economic development of a country is more than just GDP, which is one of the dimensions of economic development. This study will not use a survey like other researchers but will however use actual tax generated compared with the expected tax of the state.

\section{Theoretical framework}

Theory of social Influence as propounded by Cialdini is a psychological theory but will, however, be used as a framework for this study. The theory of social influence as accessed from changing minds explains thus: In 1984, Cialdini [24] published Influence, where he discussed on topics like; reciprocity, social proof, liking, authority and scarcity. Reciprocity: it is a belief that when you give you expect in return. It is natural that when taxes are paid government should put the funds to judicious use. Consistency and commitment: this is an idea where government made promises to provide amenities, when this is done the taxpayers are inclined to pay their taxes. Social Proof: this shows lack of policy implementation where people evade tax and are not punished, copy and the cycle continues. Liking: when the citizens see good governance they feel liked and are obliged to do their civic duties. Authority: when a citizen knows that by not paying his tax there is consequence for not paying, he has no option than to pay. Scarcity: if government knows without acting in order to generate money through tax today, then the inevitable will happen, that is, lack of money to run the state.

\section{Method of Data Collection and Analysis}

To generate data for this study, Internally Generated Revenue (IGR) of the state from 2011 through 2016 was extracted from a report from National Bureau of Statistics (NBS), Joint Tax Board and Boards of State Internal Revenue. The IGR comprise of revenue from the Ministries, Departments and Agencies (MDAs), Pay As You Earn (PAYE), other taxes, road taxes and direct assessment. The challenge of tax evasion comes from personal income tax; taxes of individuals in business. Records from Corporate Affairs Commission (CAC) shows 105 businesses are registered in Yobe state. From this list, 57 are registered in Damaturu the state capital, 26 in Potiskum and 6 in Bade local government areas where there are a lot of business activities. The list has 19 educational institutions and 13 Health and Medical which are exempt from paying taxes in Nigeria. In 2016 where the state had relative peace, more than 100 businesses are not registered as such evade tax. This is taken into consideration in generating the expected IGR in the state. Literacy rate, one of the dimensions of HDI will be used in this study. The Federal Allocation Committee Report on sources of government revenue would be examined; equally important are scholarly literature, CBN fiscal policies and the strategic planning of the government and data will be sought from the office of the Voluntary Assets and Income Declaration Scheme (VAIDS). Chi-square is employed to analyse the data generated using Statistical Packages for Social Sciences (SPSS) version 20.

\section{Data presentation}

The Table 1 contains the population of the state, expected and actual IGR and literacy rate of Yobe state from 2011 to 2016. Tables 2 and 3 show that literacy level is strongly associated with tax evasion with value of 4.78 , df 1 and significant level 0.02 .

The result of the analysis shows tax evasion has significant effect on the economic development of Yobe state and it is a confirmation of Okafor [23] research. This is one of the reasons why the HDI and the educational index of the state are as low as 0.1063 and 0.3703 respectively and that of a state like Lagos are 0.5245 and 0.977

\begin{tabular}{|l|c|c|c|c|}
\hline \multicolumn{2}{|c|}{} & \multicolumn{3}{|c|}{ IGR } \\
\hline Year & Population & Expected & Actual & Literacy rate \\
\hline 2011 & $2,765,286$ & $2,461,207,275$ & $2,385,653,777$ & 26.6 \\
\hline 2012 & $2,863,785$ & $1,936,328,058$ & $1,785,221,061$ & 25.5 \\
\hline 2013 & $2,965,792$ & $3,298,666,605$ & $3,072,006,110$ & 24.34 \\
\hline 2014 & $3,071,433$ & $3,451,547,653$ & $3,073,780,161$ & 23.7 \\
\hline 2015 & $3,180,836$ & $2,780,204,916$ & $2,251,330,427$ & 10.0 \\
\hline 2016 & $3,294,137$ & $4,480,202,318$ & $3,800,220,832$ & 7.23 \\
\hline
\end{tabular}

Table 1: Internally Generated Revenue (IGR) [Data Source is from National Bureau of Statistics/2015 National Education Survey (NEDS)/ Joint Tax Board/ State Boards of Internal Revenue]. 
Citation: Ellawule A (2018) Effect of Tax Evasion on Economic Development of Yobe State, Nigeria. J Account Mark 7: 262. doi: 10.4172/21689601.1000262

\begin{tabular}{|l|c|c|c|}
\hline Tests & Value & df & Asymp. Sig. (2-sided) \\
\hline Pearson Chi-Square & $30.000^{\mathrm{a}}$ & 25 & 0.224 \\
\hline Likelihood ratio & 21.501 & 25 & 0.664 \\
\hline Linear-by-Linear association & 4.785 & 1 & 0.029 \\
\hline No. of valid cases & 6 & & \\
\hline
\end{tabular}

Asymp. Sig: Asymptotic Significance; a Constant, IGR (expected).

Table 2: Chi-Square tests.

\begin{tabular}{|c|c|c|c|c|}
\hline Model & R & R Square & Adjusted R square & Std. Error of the estimate \\
\hline 1 & $0.604^{\mathrm{a}}$ & 0.365 & 0.207 & 7.65153 \\
\hline \multicolumn{4}{|c|}{ Table 3: Model summary. }
\end{tabular}

respectively. The effect of VAIDS introduced by the government has not been felt because the study does not extend to 2017 which is the period for the programme. From the outcome of regression analysis in table $2, \mathrm{R}^{2}$ is $37 \%$ and this means $63 \%$ of the effect of economic development of the state is due to other factors other than tax. This could be poor governance, insurgency, and lack of production in the state, etc. This is a clear evidence of the theory of influence; social proof, liking and consistency and commitment. People evade tax because of lack of performance by government and lack of policy implementation.

\section{Recommendation and Conclusion}

In conclusion, governments all over the world need revenue to run the affairs of their states. This fund is however not sufficient due to tax evasion by some companies and individuals. This has afforded the researcher the opportunity to determine the effect of this tax on the economic development of Yobe state, Nigeria.

The study recommends amongst others that the government of Yobe state improves on the lack of tax law implementation, looks into issues of inadequate and lack of qualified personnel in order to assess more businesses to tax, improve security situation of the state to enable the people farm and feed themselves and good governance in other to reduce or eliminate tax evasion in the state. It is advised that further studies be carried out to determine the effect of other factors like farming produce and industrial produce on the economic development of Yobe state and a comparative analysis of pre and post VAIDS programme implementation on the economic development of the state.

\section{References}

1. Fagbemi TO, Uadiale OM, Noah AO (2010) The ethics of tax evasion: Perceptual evidence from Nigeria. European Journal of Social Sciences 17: 360-371.
2. Nightingale K (2002) Taxation theory and practices, (4th edn.), England England Pearson Education Ltd.

3. Lymer A, Oats L (2010) Taxation policy and practice (16th edn.), Birmingham: Fiscal Publication.

4. Murkur GA (2001) Design of tax systems and corruption. Conference pape on fighting corruption: common challenges and shared experiences. Konard Adenauer Stiftung and the Institute of International Affairs (SIIA), Singapore.

5. Naiyeju JK (1996) Improving the tax system from Canadian experience, Lagos.

6. Introduction to taxation (2014) Institute of Chartered Accountants of Nigeria.

7. Odusola A (2006) Tax policy reforms in Nigeria. Research Paper, UNU-WIDER, United Nations University (UNU).

8. Gurama Z, Mansor M, Pantamee AA (2015) Tax evasion and Nigeria tax system: an overview. Research Journal of Finance and Accounting 6.

9. Adebisi JF, Gbegi DO (2013) Effect of tax avoidance and tax evasion on personal income tax administration in Nigeria. American Journal of Humanities and Social Sciences 1: 125-134.

10. Advanced Taxation (2014) Institute of Chartered Accountants of Nigeria (ICAN)

11. Lamb M, Lymer A, Freedman J, James S (2004) Taxation: an interdisciplinary approach to research. New York: Oxford University Press.

12. Owens J (2006) Tax in a boarderles world. The OECD Observer No. 257, pp: 10-11.

13. Deloitte (2013) Highlights of Nigerian international tax.

14. Ndubuisi $F$ (2017) In new executive order, Osinbajo gives tax defaulters nine months to pay up. This Day.

15. Opejobi S (2017) Osinbajo signs executive order on asset declaration. Dailypost.

16. VAIDS aimed at correcting Nigeria's poor tax to GDP ratio (2017) Vanguard

17. ABWA (2009) Accounting technician scheme. Abuja: ABWA Publishers

18. Sen A (2001) Development as freedom Oxford: Oxford University

19. Booysen F (2002) An overview and evaluation of composite indices of development. Social indicators research 59: 115-151.

20. UNDP (1990) Human Development Report 1990.

21. Popoola N (2009) A good tax system will enhance economic development Punch.

22. National human development report (2015) Human Security and Human development in Nigeria.

23. Okafor RG (2012) Tax revenue generation and Nigerian economic development European Journal of Business and Management 4: 49-56.

24. Cialdini R (1984) Influence: The psychology of persuasion, New York: Quill. 